\title{
Gender equality and religion: A multi-faith exploration of young adults' narratives
}

\section{Sarah-Jane Page}

\section{Andrew Kam-Tuck Yip}

\begin{abstract}
This paper presents findings from research on young adults in the UK from diverse religious backgrounds. Utilizing questionnaires, interviews, and video diaries it assesses how religious young adults understood and managed the tensions in popular discourse between gender equality as an enshrined value and aspirational narrative, and religion as purportedly instituting gender inequality. We show that, despite varied understandings, and the ambivalence and tension in managing ideal and practice, participants of different religious traditions and genders were committed to gender equality. Thus, they viewed gender-unequal practices within their religious cultures as an aberration from the essence of religion. In this way, they firmly rejected the dominant discourse that religion is inherently antithetical to gender equality.
\end{abstract}

\section{Keywords}

Agency, division of labour, gender equality, religious stigmatization, women's religious leadership 


\section{Introduction}

Gender equality has become a core ideal in social, political, and policy discourse in recent decades in European countries (e.g. Hubert and Stratigaki, 2011; Inglehart and Norris, 2003; Lombardo et al., 2009; Squires, 2007; Verloo, 2007). However, the meaning of 'gender equality' is contested, with intra and inter-cultural and geopolitical variations (Ferree, 2009; Lombardo et al., 2009). Attachments to gender equality inform the way national identities are imagined and constructed, as citizens and politicians align themselves with gender equality principles (Bygnes, 2012).

Within the European context, there is a pervasive perception that ethnic minority and religious communities are falling short of the ideal of gender equality (Bygnes, 2012; Petzen, 2012; Roggeband and Verloo, 2007). Indeed, although often implicit, popular and academic discourses persistently associate gender equality with whiteness and secularism (Alcoff and Caputo, 2011). One of the outcomes of using gender equality to measure the status of ethnic and religious minority groups is that it constructs the majority (i.e. 'white' and 'secular') society as having achieved gender equality, with minority groups needing to 'catch up'. This construction not only reifies and homogenizes 'gender equality' and 'religion' (and 'secularism' for that matter), but it also reinforces neo-colonial ideas about what counts as being 'modern' and 'civilized' (Bracke, 2008; McClintock, 1995; Razack, 2004). In this regard, it is often Muslim minorities who are singled out and associated with gender unequal practices (Erel, 2011; Mahmood, 2011; Mojab, 2001; Razack, 2004). Nevertheless, other religious traditions and spaces are also implicated (e.g. the denial of priesthood to women in the Catholic Church). The association between gender equality and secularism is reinforced, while religion is essentialized as inherently antithetical to gender equality (e.g. Spierings and Zaslove, 2015). Undoubtedly, gender-unequal religious practices and spaces exist (e.g. Denton, 2004; Inglehart and Norris, 2003; Nynäs and Yip, 2012; Ozorak, 1996; Page, 2012; 
Houston, 2012; Stuart, 2010; Trzebiatowska and Bruce, 2012; Woodhead, 2007).

Nonetheless, the lived reality is complex and nuanced, as we shall argue throughout this paper.

The relationship between religion and gender equality has been heightened due to the changes in women's lives over the latter half of the $20^{\text {th }}$ century, particularly women's increased participation in the public sphere, through paid work and education (Inglehart and Norris, 2003; Marler, 2008; Woodhead, 2002, 2008). Although gender inequalities persist in the public sphere, they remain entrenched in the private sphere (Breen and Cooke, 2005; Gatrell, 2005). In the past two decades, the multi-faceted politicisation of Islam and the controversy surrounding access to religious leadership in Christianity have also intensified the debate about religion's resistance to the promotion of gender equality. Indeed, women's lack of access to leadership roles in some religious institutions has been taken as an indicator of religious alignment with gender inequality. As Woodhead (2007) has argued, this scenario may not even be due to religious traditions lagging behind other social spheres; rather it can reflect concerted attempts by conservative religious traditions to resist feminist ideas.

Scharff's $(2011,2012)$ empirical investigation of young women highlights that they see themselves, and are perceived by others, as embodying gender equality. This highlights the fact that gender equality is not only a norm, an ideal, but it is also a lived experience. But her research also clearly shows that this embodiment of gender equality is a classed and raced phenomenon, with privileged white, middle-class young women best-able to capitalize on this rhetoric. Scharff's non-Muslim participants invoked the 'oppressed Muslim woman' as the 'Other' that represented gender inequality, and against which they positioned themselves (see also Erel, 2011).

This raises questions about how religious individuals - women and men - make sense of gender equality when gender itself has undergone enormous change. If religion (and not 
just Islam) is understood as the space within which gender inequality is ubiquitous, then how do religious young adults position themselves in relation to the religious traditions to which they belong? Do they too understand their religious traditions as repositories of gender inequality? And how do they frame their own identities in relation to this? These are the key questions that this article seeks to explore.

The article will cover four empirical themes. We shall explore firstly our participants' perceptions of the stigmatization of religion in British society, which is in part informed by the popular view that religion is intrinsically gender-unequal. This contextualizes the examination of the participants' diverse understandings of their religions' gender expectations in the second theme. In the third theme, we shall focus on religious leadership, to which women's access is denied in some contexts. Finally, we turn the spotlight on the private sphere, specifically the domestic division of labour. We choose to focus on these areas in the last two themes because, in our view, they represent two of the most contentious areas which underpin the broader discourse of religion and gender equality.

\section{Methodology}

This article is based on a research project entitled Religion, Youth and Sexuality: A MultiFaith Exploration. Focusing on young adults aged 18 to 25 in the UK - from diverse religious backgrounds and various sexualities - the project aimed to examine the participants' management of their religious, sexual, youth, and gender identities in everyday contexts.

We employed diverse sampling strategies to maximize participant variability, including: publicity postcards/posters/e-mails to a wide range of groups (e.g. university religious and cultural student groups, and support groups for sexual minorities), snowball sampling, personal networks, advertisements in printed and online media, a project website, as well as a Facebook page. Therefore, the project's participants constitute an 
unrepresentative heterogeneous sample (Spencer and Pahl, 2006) that is based on two key criteria: religious self-identification (specifically Christian, Muslim, Hindu, Sikh, Jewish, Buddhist $^{1}$, and any combination of these labels [i.e. mixed-faith]); as well as sexual selfidentification.

We acknowledge the unrepresentative nature of our sample, recruited through diverse sampling strategies. Therefore, we would caution against generalizing our findings across the religious young adult population in Britain and elsewhere. Nonetheless, our study's substantial sample size and the extensive and in-depth data it has generated offer illuminating insights into contemporary young adults' religious, gendered, and sexual identities.

Being mindful of the respective strengths and limitations of all research methods, we adopted a mixed-method research design, comprising three stages: (1) an online questionnaire; (2) interviews; (3) video diaries. This design enabled the maximization of the overall sample size via the first method, although we acknowledge the possibility of participants' differing interpretations of fixed questions in the researchers' absence. The second and third methods enabled us to generate 'thick descriptions', but they were more time-consuming, costly, and labour-intensive.

The online questionnaire, containing 38 open and closed-ended questions, aimed to document participants' views and experiences on a range of issues pertaining to their religion, sexuality, gender and being young adults in society. In total, 693 participants completed the questionnaire.

The questionnaire was employed not only to collect primarily quantitative data, but also to serve as a selection strategy for the constructions the sub-samples for interviews and video diaries (Seawright and Gerring, 2008). At the end of the questionnaire, participants were invited to leave their contact details if they were willing to be interviewed. Participants who responded positively were included in a sampling frame, and 61 were selected on the 
basis of participant variability maximization, and they were interviewed for about two hours each.

Each interviewee was invited to take part in the video diary, whereby participants recorded her/his reflections over seven days. This enabled participants to record their 'mundane' and significant reflections. In total, 24 participants completed this stage (for more details about the research design and tools, see Yip and Page, 2013).

The percentages we present in this paper are calculated based on the valid responses to questions in the questionnaire, analyzed using SPSS. The qualitative data was drawn from all three methods, analyzed using a thematic approach.

The participants' religious self-identifications include: Christian (57.1\%), Muslim (16.6\%), Jewish (7.5\%), Hindu (6.8\%), Buddhist (4.5\%), Sikh (3.8\%) and mixed-faith $(3.7 \%)$. Constituting $65.7 \%$ of the overall sample, women outnumbered men across all religious categories. In addition, $74.3 \%$ of the participants defined themselves as 'heterosexual', followed by $17.5 \%$ who self-defined as 'lesbian', 'gay', 'homosexual' or 'bisexual'. Furthermore, $64.9 \%$ also self-defined as 'white' and $72.4 \%$ were students (for more details, see Yip and Page, 2013).

\section{Stigmatization of religion in British society}

In the questionnaire, we asked participants to what extent they agreed or disagreed with the statement, 'Religious people are stigmatized in Britain'. Overall, 68.0\% $(\mathrm{n}=565)$ agreed or strongly agreed with this. Thus, religious stigmatization was an important concern for our participants generally. Across the religious categories, Christians and Muslims demonstrated the highest levels of agreement: $75.3 \%(n=328)$ and $69.7 \%(n=89)$ respectively. Meanwhile, Hindus and Buddhists had the lowest rates of agreement, with $45.7 \%(n=35)$ and $46.4 \%$ $(n=28)$ respectively. That Christian and Muslim participants were more likely to agree with 
the statement reflects the construction of different religions within the broader socio-cultural and political context in British society. Compared to other religions, Christianity and Islam are certainly more scrutinized and challenged, in part due to high-profile controversies surrounding gender issues (e.g. veiling practices, and women's access to religious leadership).

Qualitative data offer a more nuanced picture about the nature of stigmatization. The basis of such stigmatization was wide-ranging, including: religion's assumed incompatibility with the dominant scientific worldview, and misunderstandings about religious beliefs and practices. Another key basis, relevant to this article, was the entrenched perception of religion as intolerant towards gender and sexual equality. Kyle, a Christian man, summed this up succinctly in his video diary: '[the idea] that Christianity is inherently sexist and homophobic is one that is quite widespread, and I don't see it as being sexist or homophobic or I wouldn't be a member of it'. But it was specifically women who had to manage and negotiate these assumptions. As a Muslim woman of Nigerian heritage, Layla's interview narrative resonates fully with Scharff's $(2011,2012)$ non-Muslim participants who made assumptions about Muslim women's bodies:

[T]hey are like, 'Oh my god, were you a victim of [genital cutting]?' I'm like, 'What the hell are you talking about? I grew up the same way you did; I wasn't oppressed by anyone or anything; I wasn't circumcised'.

However, this experience was not limited to the Muslim women in our sample; rather, it was experienced more broadly by young women from religious and ethnic minority backgrounds. Uma, a Sikh woman, said in her interview: 
At school my best mates were predominantly white, so if they had a boyfriend, they were allowed to bring them home. Whereas my Asian friends, they still had to lie... even when I was having these arguments at home I never used to really tell my friends because...I didn't want to be labelled a typical Asian girl that hasn't got any freedom, kept at home [doing] housework. I just didn't want to be labelled that because I was like, I'm better than that.

Uma highlighted the complexity of the stereotype of the 'typical Asian girl'. On the one hand, she wanted to challenge this perception because it made her feel inferior to her nonAsian friends; but on the other hand, this meant she was unable to give voice to the difficulties she was experiencing, particularly confrontations with her parents over freedoms that she saw her non-Asian friends taking for granted. Our qualitative data demonstrates that tropes of gender oppression are not only aligned with the bodies of Muslim women, but are experienced more broadly by women of different religious traditions. Ethnicity also made a huge difference. We found little evidence of white women within our sample of religious young adults experiencing similar stereotyping. Uma highlighted that it was not her being a Sikh that led to her being potentially labelled as oppressed, but how she was racialized as 'South Asian': a reified category that was perceived in the broader society as the embodiment of gender inequality, structured by illiberal ethnic and religious norms.

Meanwhile, Adala, a Muslim woman, talked about the specific connotations attached to being Pakistani and Muslim, and how this combination heightened public perceptions about her supposed susceptibility in experiencing gender-conservative practices:

[A] lot of people said to me, 'It's really good how you've been to university because a lot of Pakistani girls just get married and they don't educate themselves' ... It's not 
just white people [who say this], it's [also] Sikh and Hindu girls. Muslim girls are frowned upon... sometimes I do feel insecure when people say that Pakistani girls aren't allowed to do this; they're no good.

Adala's narrative highlights that the intersection of religion and ethnicity can amplify and intensify stereotyping in the public imagination. This was experienced most profoundly by the Muslim women belonging to an ethnic minority group in our sample, who reported negativity emanating from not only white individuals, but also other minority ethnic-religious individuals. This reflects the pervasive and essentializing construction of the 'Muslimwoman' (Cooke, 2007), not only within the white community, but also within other non-Muslim ethnic-religious minority communities. As Petzen articulates, in 'debates on the integration of "Muslim" women over the last decade, racialized notions of gender and sexuality have become central markers in the distinction between acceptable and unacceptable ways of being European', with Muslim women understood as posing 'a threat to supposedly stable European values and a democratic gendered order' (2012: 98). From this perspective, Muslim women are reified as being victims of gender oppression and representing a population where gender equality policies have failed. Thus, Muslim women are positioned as agency-deprived (Petzen, 2012).

In this section, we have demonstrated the way the public imagines the complex intersection of gender and religion. Potent stereotypes are often discursively produced, whereby some bodies - specifically those of ethnic and religious minority women - are marked as carriers of gender inequality and even gender violence (i.e. female genital mutilation), regardless of whether this is actually reflected within lived experience. These sweeping assumptions and framings are so powerful that they disrupt young women's ability 
to articulate the gender inequalities they actually experience.]. We shall now consider the participants' perceptions of gender within their own religious traditions.

\section{Perceptions of religious gender expectations and requirements}

Amongst our sample, 63.4\% $(\mathrm{n}=625)$ strongly agreed or agreed with the questionnaire statement that 'My religious tradition emphasizes equality of the sexes', with $59.7 \%(\mathrm{n}=$ 417) of women and 70.5\% $(\mathrm{n}=207)$ of men holding this view. Table 1 offers a more detailed picture, by religious identification and gender.

\section{Insert Table 1 here}

Table 1 shows that all religious identification and gender categories have a majority that perceived their religious tradition as being gender-equal, except three: Jewish women (35.7\%), Jewish men (33.3\%), and Hindu women (20.8\%). Except in the case of Jewish participants, men were more likely than women to uphold this view. With reference to the previous theme, it is interesting to observe that, contrary to popular discourse that Muslim women were the most oppressed, $77.1 \%$ of our Muslim women participants believed that their religious tradition was gender-equal. This is the second highest percentage across all seven religious categories.

Furthermore, only $27.9 \%(n=620)$ of the overall sample strongly agreed or agreed with the questionnaire statement that 'My religious tradition prioritizes the interest of men'. We found little gender variation overall, with $28.7 \%(n=413)$ of women and $27.2 \%(n=$ 206) of men holding this view. Table 2 offers a more detailed picture, by religious identification and gender. 


\section{Insert Table 2 here}

These statistics indicate that, broadly speaking, young adults in our sample identified gender equality within their religious tradition. As the qualitative data will demonstrate, even those who were critical, usually insisted that this was an aberration of the core ideals of their religious tradition. Indeed, the participants emphasized that gender equality was a nonnegotiable norm. This is epitomized by Jai, a Hindu man, who said in interview:

I feel like both genders have to be equal in every sense. I cannot absolutely relate to any gender being inferior to the other, and I've always believed, very strong beliefs that I have that there should be absolute gender equality.

Lauren, a Buddhist, argued in her questionnaire that all religious traditions should espouse gender equality: 'Men and women should be treated as equals under any religion'. But although some positively affirmed gender equality within their religious traditions, others were explicitly critical, as represented in the following quotes:

What my religion teaches me is equality. That is one of the biggest fundamentals of Sikhism... [But] at the temple, in the committees, it's mainly men (Ajeet, Sikh man; interview)

Islam has been distorted by men to oppress women. The Qur'an gives women rights... But the Islam practised by the majority refers to other scripture to promote gender inequality. (Amreen, Muslim woman; questionnaire) 
Both Ajeet and Amreen drew a clear line between the essence of their religion (i.e. God's sacred intention for gender equality), and institutional and cultural practices perpetuated by religious authority elites (usually men) to legitimize gender inequality. These participants placed gender inequality into the more amorphous concept of 'culture' (Bolognani and Mellor, 2012; Contractor, 2012). This is a strategic tool utilized by participants who were fully aware that, institutionally, their religious traditions were infused with gender-unequal norms and practices, falling short of the perceived sacred essence of their religions.

Finally, some participants endorsed the view that their religion had been misunderstood. They asserted that although some religions might have specific gender expectations for women and men, this did not constitute inequality per se, as the following questionnaire quotes demonstrate:

In Judaism, the sexes have different roles but these may be due to functionality, rather than sexism. (Lara, Jewish woman)

Men and women are equal but are not the same. As a man I should expect to take responsibility in leadership and providing for others. (Tom, Christian man)

These participants were clear that gender role demarcation did not imply inequality. Put differently, equality did not mean 'sameness' in the performance of social roles. To them, gender role specialization reflected an appreciation of the different qualities and strengths that each gender could bring. While the majority of our participants argued that religions which denied certain roles to women were gender-unequal, these participants endorsed gender complementarity, which is the 'dualistic view of humanity in which men and women are seen as essentially different from each other, and are often thought in that "difference" to display 
“complementarity"' (Shaw, 1998: 14). Rhetorically, these participants were highly committed to gender equality, emphasizing painstakingly that although they agreed with gender difference manifested through role differentiation, this did not negate their support of gender equality. However, as we shall see in the following two themes, narratives supporting role differentiation and complementarity were fragmented and became inconsistent as participants made sense of how they wished to live their everyday lives as men and women.

\section{Religious leadership}

Access to religious leadership has long been a contentious issue in the debate about religion, gender, and equality. Amongst our own sample, only $18.3 \%(n=627)$ strongly agreed or agreed with the statement that 'Religious authority figures (e.g. clergy) should be male'. A smaller proportion of women $(16.7 \% ; n=419)$ compared to men $(21.7 \% ; n=207)$ held this view. Table 3 offers a more detailed picture, by religious identification and gender.

\section{Insert Table 3 here}

Table 3 shows that, across religious identification and gender categories, the support for men's exclusive access to religious leadership was generally minimal, except in the cases of Muslim men (46.7\%), Muslim women (29.8\%), and Christian men (26.2\%). No group had majority support for an exclusively male leadership.

Many participants considered women's access to religious leadership as a crucial symbol of equality, reflecting the establishment of gender equality in wider society. This is typified by the interview narrative below: 
I believe that God creates everyone to have the opportunity to serve him in whatever capacity. So I think if a woman is called to be a bishop, then great, it is no different to a man being called to be a bishop... It isn't long ago that we had a female primeminister... It doesn't make any sense to me that people should even be commenting on [women's leadership]. (Aaron, Christian man)

Narratives such as Aaron's reflect a secular and sacred basis for gender equality. In other words, women should have access to religious leadership not only because it is consistent with developments in broader society, but it also demonstrates the implementation of God's plan for humanity, that women and men serve side-by-side, as equals. Sacred and secular endorsements of equality complemented and strengthened each other in such accounts.

Meanwhile, the minority of participants who saw gender equality as compatible with role differentiation argued that women's religious leadership was not practical, given the other roles (e.g. motherhood) they had to manage. Layla, a Muslim woman, asserted this in the interview:

[W]e are equal, you know. [T] here is this saying... equal but different ... Islam is into marriage and having kids... [so] nine months you would be carrying a child, giving your [child] the best of care. Juggling being a leader for [the] Islamic community and all that really doesn't [work].

Layla sanctioned motherhood as the primary and sacredly-endorsed identity for women, foreclosing the possibility of being a religious leader. Clare, a Christian woman, also endorsed role differentiation, arguing that 'women and men have different roles', but then 
contended that 'I don't really like the idea that if you were very good at something, that you can't do it'. Instead, she endorsed married couples working together as religious leaders:

I think the best person to lead a church is a couple. I don't think it's one or the other. I think there's a very good compromise in a relationship.

By endorsing couple-based leadership, Clare was able to affirm women's leadership whilst also remaining committed to gender complementarity. However, this envisioning demonstrates an entrenched heteronormative understanding of what constitutes 'good' coupledom and 'effective' religious leadership.

In a culture where middle-class women are now expected to pursue a career, and all women are expected to participate in the labour market in some capacity (e.g. Budgeon, 2011; Press, 2011), women's lack of access to religious leadership is an anathema. Indeed, many participants considered gender equality concomitant to religious leadership. Even the minority endorsing gender complementarity were uneasy at the prospect of women being denied access to leadership roles and sought ways to integrate women's religious leadership in a way that corresponded with their views of gender.

\section{Family life and the domestic division of labour}

As research has consistently shown, the advancement of gender equality in the public sphere is often not reflected in the private sphere. Despite men's increasing participation, women continue to undertake the bulk of domestic and caring work (e.g. Breen and Cooke, 2005; Gatrell, 2005).

In general, our participants expressed minimal support for gender role specialization in the private sphere. Overall, only $38.6 \%(n=625)$ strongly agreed or agreed with the 
statement that 'Men should provide financially for the family'. A slightly smaller proportion of women $(36.9 \% ; n=420)$ compared to men $(42.2 \% ; n=204)$ held this view. Table 4 offers a more detailed picture, by religious identification and gender.

\section{Insert Table 4 here}

Table 4 shows that Muslim women (67.5\%) and Muslim men (81.3\%) were the only categories that had a majority in upholding men's role in financially providing for the family.

Overall, only $21.4 \%(n=627)$ strongly agreed or agreed with the statement that 'Women should have primary responsibility for bringing up children'. A greater proportion of women $(21.7 \% ; \mathrm{n}=419)$ compared to men $(20.7 \% ; \mathrm{n}=208)$ held this view. Table 5 offers a more detailed picture, by religious identification and gender.

\section{Insert Table 5 here}

Table 5 shows that Muslim women (43.4\%) and Muslim men (40.0\%) were more likely than other religious identification/gender categories to uphold the traditional view about women's role in child rearing. It is interesting to observe that, in the area of family life and domestic division of labour - and in the area of religious leadership (discussed in the preceding theme)

- Muslim participants were more likely, compared to other religious groups, to uphold a conservative gender view that prioritizes men's role in the public sphere as leader and provider, and women's role in the private sphere as carer.

Many of our participants were single, so few had directly experienced the dual demands of paid and unpaid work. But their views about equality and the gendered division of labour were informed by three intersecting factors: their religion, the attitudes and 
practices of their family of origin, and broader secular norms. In some cases, these three factors converge, but in other cases, they compete. The following narratives, all drawn from the interviews, demonstrate some of the outcomes of these intersections, highlighting the diverse contexts in which the participants operationalized their understanding of gender equality. Parminder, a Sikh woman, emphasized how all three factors were mutuallysupporting and mutually-constitutive in her life, leading to a gender-egalitarian outcome:

A lot of my cousins that are in their late 20 s... are having kids. I see their relationships a lot more equal to what it is with our parents' and even our grandparents'. Our grandparents' generation very much was: woman stays at home, has kids, husband goes out to work.... Now our generation is completely different... it is more equal... There is a lot of emphasis placed on equality of men and women within the temple and they like to promote it... [M]y parents both work; they always have... my mum does all the housework... my dad, he does do hoovering now and again, but that is just the way it's been done.

Parminder endorsed herself and her family as following a gender-egalitarian script, making it hard for her to critically reflect on instances of inequality (e.g. her mother fulfilling the 'double shift'). Other participants were more critical of the inequalities they encountered. For example, Isma, a Muslim woman, argued in the interview:

When I was growing up it was like me against the family who were traditional. So they have the father, the head of the family, the males who are seen in the culture as dominating, the people who go out and earn the bread... The cultural role for a woman is to stay at home, be a home maker, bear [a] child and be a wife and all that 
kind of tosh that I don't agree with. Whereas the religion says you can be who you want as long as you recognize that... you have a role in motherhood and as a wife.

Implicit in Isma's account is the recognition of the wider opportunities for women, particularly in the workplace. Isma wanted to benefit from these opportunities. Unlike Parminder, Isma found evidence of gender injustice in her family, which militated against her reaching her educational and career goals. She therefore utilized religion to support her aspirations. But this was a double-edged sword, due to her recognition of the religious expectation to complement a career with being a good wife and mother.

Overall, the men in our sample were less reflective about private-sphere gender regimes. Nevertheless, Jai, a Hindu man, provided an extensive narrative about his different gender expectations as a consequence of growing up in India and now living in the UK:

[Hinduism] is quite positive to gender equality because even in the epics you have goddesses... Hindu society probably treats women to be inferior in general, but Hinduism as a religion... it's quite conducive for women... I've always believed that there should be absolute gender equality... [My parents are] quite liberal... But subtly you can see that there is a superiority of the man to the woman... I cannot get my head around, say, women have to clean the house and the man has to work. Personally I feel that it should be shared... [I]n my present relationship, I cook better, so usually I cook, but it wouldn't be accepted in India because that's not the way it's supposed to be.

Jai recounted the contradictions he had witnessed regarding gender norms in the spheres of religion, family and broader culture. Despite these contradictions, he was clear that gender 
equality was a non-negotiable norm that he wanted to practise in his own relationship. Jai's narrative highlights that a strict division of labour not only impacts on women's choices, but can also curtail the options available to men.

For participants such as Jai, gender equality meant equal opportunities for women and men to flourish. Participants expressed strong support for women to be in paid employment, and to develop their own careers, and for this to be alongside motherhood. However, this could result in tensions in conceptualizing equality, especially for those endorsing gender complementarity. We met Layla in the last section and saw that she firmly believed that motherhood would conflict with being a religious leader. However, her views on women's participation in paid work were rather different:

I'm not going to be a housewife; God gave me a degree not to be sat at home... if I had a child and I knew there would be no one sufficient enough to take care of them, for the first three years, I wouldn't mind staying home yes, as long as I'm going to go back to work

As we can see from Layla's case, views of gender complementarity and role differentiation become much harder to sustain in environments where there is a broader cultural emphasis on women's engagement in paid work, resulting in contradictory narratives. She strategically deployed God as the sacred legitimization for her aspiration for paid employment. She did not denounce gender complementarity, but contained it, applying it only to her child's early years. However, the contradiction is less evident in Layla's rationalization about women's access to religious leadership, because she was less invested in this respect, as she did not aspire to be a religious leader. 


\section{Conclusion}

This paper has presented qualitative and quantitative findings from a mixed-method research project of 693 religious young adults in the UK. It represents a significant development on previous work in three respects. First, it includes the voices of young men, who are often not called to account for their perspective on gender. Second, its multi-faith approach gives space to voices from diverse religious backgrounds. Finally, its mixed-method approach allows us to explore this issue of gender equality and religion through both qualitative and quantitative means.

The paper focuses on gender equality, which was an important issue for our participants. Our overwhelming finding was the unequivocal support the participants expressed for gender equality as a non-negotiable ideal. However, the meanings attached to gender equality varied. Most conceptualized gender equality as sameness, but a minority argued that equality could also be achieved through sacredly-informed role specialisation and complementarity. This diversity of understandings is reflected explicitly in the two areas that we have chosen to explore: religious leadership, and the domestic division of labour. Tensions were evident as participants attempted to valorize religious and secular scripts in their rationalizations. In their attempts to position themselves as gender-equal subjects where gender equality itself was contentious, the participants engaged with both secular and religious norms that were at times mutually-reinforcing, yet competing at other times. They neither uncritically subjected themselves to, nor completely rejected, religious norms and traditions. Rather, they utilized religion as a 'cultural resource' (Beckford, 2001) - as opposed to a set of non-negotiable diktats - alongside secular norms in finding an ontological anchor. This leads to outcomes that were negotiated and contingent. This agentic process of reflection was sometimes characterized by ambivalence, which itself generated a form of 'creative 
tension' that served as an impetus for ongoing reflection and negotiation (Yip and Page, 2013; see also Hoel, 2015).

In terms of gender differences within the sample, at an attitudinal level, men and women drew on similar cultural scripts: that gender equality should be the organizing principle of everyday life. Men as well as women were critical of gender-unequal practices. But there were experiential differences. Men were less reflexive about the implications of gender inequality; and women were more likely to be implicated in the management of gender-unequal practices. Men's bodies - and some women's bodies - were rarely invoked as representations of gender oppression. What made the difference in these representations is the way bodies are gendered and racialized. A hierarchy emerges amongst women, where religious and ethnic minority women - especially Muslim women belonging to an ethnic minority group - were marked out as embodying gender inequality in the public imagination. This emphasizes the complex ways in which 'religion' is invoked in broader discourses which routinely emphasize religion's (especially Islam's) assumed propensity towards gender inequality. Whereas white religious women can downplay their religious identity and associate themselves with a femininity emphasizing choice, freedom and autonomy, ethnic minority religious women are co-referenced in relation to both their (assumed) religious identity and ethnicity, producing negative connotations of gender inequality. This representation could indirectly result in the silencing of some ethnic minority and religious women in voicing experiences of gender inequality. Owing to their awareness of the biased and entrenched representation of them as being oppressed by virtue of their association with ethnic minority and religious communities, they became reticent in articulating such lived experiences, if any, for fear of compounding the already negative but powerful representation of them and their communities. 
Indeed, despite the fact that the vast majority of our participants believed that the essence of their religions espoused gender equality, they were conscious of how religion was positioned negatively in dominant discourse. Participants demonstrated strong support for women's religious leadership, and little support for gender role specialization in the private sphere. In making sense of this, they were informed by three factors: family norms, religious faith and spaces, and secular values. Despite gender complementarity being strongly associated with various religious edicts (Inglehart and Norris 2003), only a minority supported this, and these views were always accompanied by a vocalised commitment to gender equality. However, when such participants were confronted with the practical outcome of these views - i.e. women's exclusion from certain roles - this did not fit easily with their broader commitment to gender equality. This is where the inconsistency between aspiration and lived reality was evident. Our participants demonstrated diverse ways of managing such inconsistency and contradiction. Such responses attest to the variety of outcomes in the exercise of agency as a form of enacting 'ethical self-formation' (Mahmood, 2005). Agency, as Mahmood (2005) has argued, is multifarious, thus does not fit neatly into the dominant but narrow progressivist construction which recognizes agency only when a subordinating norm is subverted or disrupted (see also Rahman, 2014). In the same vein, we have also argued elsewhere (Yip and Page, 2013) that religious young adults were engaged in an ongoing agentic process of 'construction of ethics of life', drawing from, and managing at times, contradictory norms and resources to construct a life they deemed meaningful and ethical.

For the most part, participants rejected the idea that their religious traditions were gender unequal, arguing that gender unequal practices in religious spaces were culturallyinformed, and at odds with the sacred core of religion that upheld gender equality. This enabled participants to assert themselves as thoroughly modern subjects, in line with liberal 
democratic norms. This strategic demarcation also emphasizes the importance of a more layered understanding of 'religion', which problematizes the entrenched propensity in popular discourse to reify and frame religion exclusively as an official power structure and dogma, thereby neglecting the agency and creativity of religious actors as individuals and as a community (Yip and Page, 2013). By adopting a more nuanced understanding of 'gender equality' as well as of 'religion', we can then begin to develop a more layered and complex understanding of their relationship.

More generally, we need to be wary of a blanket approach that positions all religions, in all contexts, as gender-unequal. The relationship between gender equality and religion must be understood in the context of broader power-infused processes and intersections. We should refrain from uncritically associating religion with particular norms of gender inequality, as if they were fixed and immutable. Indeed, although some forms of institutionalized religion have undoubtedly contributed to the perpetuation of gender inequality, religious adherents have also used diverse strategies to challenge unequal norms and practices in everyday life, despite the tensions and ambivalence this may generate (Bracke, 2008; Contractor, 2012; Ozyegin, 2015; Pears, 2004; Vincett et al., 2008; Wadud, 2006; Woodhead, 2002; Yip and Page, 2013).

\section{Acknowledgment}

The research team would like to thank the AHRC/ESRC-funded Religion and Society Programme for funding this project (2010-2012; Award no. AH/G014051/1]. We also wish to express our gratitude to the invaluable contribution from the participants, individuals and groups who helped with the recruitment of the sample, and the members of the advisory committee. The research team consisted of Prof. Andrew Kam-Tuck Yip (Principal Investigator), Dr. Michael Keenan (Co-investigator) and Dr. Sarah-Jane Page (Research 
Fellow). More details of the project can be found at http://www.nottingham.ac.uk/sociology/research/projects/rys. We also thank the editors and the anonymous reviews for their helpful feedback on earlier drafts.

\section{Notes}

1. This reflects the six major religions in the UK, consistently shown in the national Census of 2001 and 2011.

\section{References}

Alcoff LM and Caputo JD (2011) Introduction: Feminism, sexuality , and the return of religion. In: Alcoff, LM and Capto JD (eds.) Feminism, Sexuality, and the Return of Religion. Bloomington: Indiana University Press, 1-16.

Beckford JA (2001) Social movements as free-floating religious phenomena. In: Fenn, RK (ed.) The Blackwell Companion to the Sociology of Religion. Oxford: Blackwell, 229248.

Bolognani M and Mellor J (2012) British Pakistani women's use of the 'religion versus culture' contrast: A critical analysis. Culture and Religion 13(2): 211-226.

Bracke S (2008) Conjugating the modern/religious, conceptualizing female religious agency: Contours of a 'post-secular' conjuncture. Theory, Culture and Society 25(6): 51-67.

Breen R and Cooke LP (2005) The persistence of the gendered division of domestic labour. European Sociological Review 21(1): 43-57.

Budgeon S (2011) Third Wave Feminism and the Politics of Gender in Late Modernity. Basingstoke: Palgrave MacMillan.

Bygnes S (2012) Gender-equality as boundary: 'Gender-nation frames' in Norwegian EU campaign organizations. European Journal of Women's Studies 19(1): 7-22. 
Contractor S (2012) Muslim Women in Britain. London: Routledge.

Cooke M (2007) The Muslimwoman. Contemporary Islam 1(2): 139-154.

Denton ML (2004) Gender and marital decision making: Negotiating religious ideology and practice. Social Forces 82: 1151-80.

Erel U (2011) Migrant women challenging stereotypical views on femininities and family. In Gill R and Scharff C (eds.) New Femininities: Postfeminism, Neoliberalism and Subjectivity. Basingstoke, Palgrave Macmillan, 230-245.

Ferree MM (2009) Inequality, intersectionality and the politics of discourse. In: Lombardo E, Meier P and Verloo M (eds.) The Discursive Politics of Gender Equality. London: Routledge, 86-104.

Gatrell C (2005) Hard Labour. Maidenhead: Open University Press.

Hoel, N (2015) Engaging Islamic sexual ethics: Intimacy, pleasure and sacrality. Sexualities 18 (1/2): 80-99.

Houston K (2012) When God is not so good: Corporate religion contra new social movements. In Nynäs P and Yip A. K. T. (eds.) Religion, Gender and Sexuality in Everyday Life. Farnham: Ashgate, 141-158.

Hubert A and Stratigaki M (2011) The European Institute for Gender Equality: A window of opportunity for gender equality policies? European Journal of Women's Studies 18(2): 169-181.

Inglehart R and Norris P (2003) Rising Tide: Gender Equality and Cultural Change around the World. Cambridge: Cambridge University Press.

Lombardo E, Meier P and Verloo M (2009) Stretching and bending gender equality: A discursive politics approach. In: Lombardo E, Meier P and Verloo M (eds.) The Discursive Politics of Gender Equality. London: Routledge, 1-18.

McClintock A (1995) Imperial Leather. London: Routledge. 
Mahmood S (2005) The Politics of Piety: The Islamic Revival and the Feminist Subject. Princeton: Princeton University Press.

Mahmood S (2011) Religion, feminism, and empire: The new ambassadors of Islamophobia. In: Alcoff LM and Caputo JD (eds.) Feminism, Sexuality, and the Return of Religion. Bloomington: Indiana University Press, 77-102.

Marler PL (2008) Religious change in the West: Watch the women. In: Aune K, Sharma S and Vincett G (eds.) Women and Religion in the West. Aldershot: Ashgate, 23-56.

Mojab S (2001) Theorizing the politics of 'Islamic Feminism. Feminist Review 69(1): 12446.

Nynäs P and Yip AKT (2012) Religion, Gender and Sexuality in Everyday Life. Farnham: Ashgate.

Ozorak EW (1996) The power, but not the glory: How women empower themselves through religion. Journal for the Scientific Study of Religion 35(1): 17-29.

Ozyegin G (2015) Gender and Sexuality in Muslim Cultures. Farnham: Ashgate.

Page S (2012) Femmes, mères et prêtres dans l'Église d'Angleterre: Quels sacerdoces. Travail, Genre et Sociétés. 27: 55-71.

Pears A (2004) Feminist Christian Encounters. Aldershot: Ashgate.

Petzen J (2012) Contesting Europe: A call for an anti-modern sexual politics. European Journal of Women's Studies 19(1): 97-114.

Press AL (2011) 'Feminism? That's so seventies': Girls and young women discuss femininity and feminism in America's Next Top Model. In: Gill R and Scharff C (eds.) New Femininities. Basingstoke: Palgrave Macmillan, 117-133.

Rahman M (2014) Homosexualities, Muslim Cultures and Modernity. Basingstoke: Palgrave Macmillan. 
Razack SH (2004) Imperilled Muslim women, dangerous Muslim men and civilised

Europeans: Legal and social responses to forced marriages. Feminist Legal Studies 12: 129-174.

Roggeband C and Verloo M (2007) Dutch women are liberated, migrant women are a problem: The evolution of policy frames on gender and migration in the Netherlands, 1995-2005. Social Policy and Administration 41(3): 271-288.

Scharff C (2011) Disarticulating feminism: individualisation, neoliberalism and the othering of 'Muslim women'. European Journal of Women's Studies 18(2): 119-134.

Scharff C (2012) Repudiating Feminism. Farnham: Ashgate.

Seawright $\mathbf{J}$ and Gerring $\mathbf{J}$ (2008). Case selection techniques in case study research: A menu of qualitative and quantitative options. Political Research Quarterly 61(2): 294-308.

Shaw J (1998) Gender and the Act of Synod. In: Furlong M (ed.) Act of Synod - Act of Folly? London: SCM Press, 14-26.

Spencer L and Pahl R (2006) Rethinking Friendship. Princeton, NJ: Princeton University Press.

Spierings N and Zaslove A (2015). Conclusion: Dividing the populist radical right between 'liberal nativism' and traditional conceptions of gender. Patterns of Prejudice 49(1-2): 163-173.

Squires J (2007) The New Politics of Gender Equality. Basingstoke: Palgrave MacMillan. Stuart A (2010) Freedom of religion and gender equality: Inclusive or exclusive? Human Rights Law Review 10(3): 429-459.

Trzebiatowska M and Bruce S (2012) Why are Women More Religious than Men? Oxford: Oxford University Press.

Verloo M (2007) Multiple Meanings of Gender Equality. Budapest: CPS Books. 
Vincett G, Sharma S and Aune K (2008) Introduction: Women, religion and secularization: One size does not fit all. In: Aune K, Sharma S and Vincett G (eds.) Women and Religion in the West. Aldershot: Ashgate, 1-19.

Wadud A (2006) Inside the Gender Jihad. Oxford: Oneworld.

Woodhead L (2002) Women and religion. In: Woodhead L, Fletcher P, Kawanami H and Smith D (eds.) Religions in the Modern World. London, Routledge, 332-356.

Woodhead L (2007) Gender differences in religious practice and significance. In: Beckford JA and Demerath III NJ (eds.) The SAGE Handbook of the Sociology of Religion. London: Sage, 566-586.

Woodhead L (2008) 'Because I'm Worth It': Religion and women's changing lives in the West. In: Aune K, Sharma S and Vincett G (eds.) Women and Religion in the West. Aldershot: Ashgate, 147-161.

Yip AKT and Page S (2013) Religious and Sexual Identities. Farnham: Ashgate. 
Tables

Table 1: $\quad$ Participants Who 'Strongly Agreed' or 'Agreed' that 'My Religious Tradition Emphasizes Equality of the Sexes'

\begin{tabular}{|c|c|c|c|c|}
\hline $\begin{array}{c}\text { Religious } \\
\text { identification }\end{array}$ & $\begin{array}{c}\text { Percentage of } \\
\text { women }\end{array}$ & $N$ & $\begin{array}{c}\text { Percentage of } \\
\text { men }\end{array}$ & $n$ \\
\hline Buddhist & 73.3 & 15 & 83.3 & 12 \\
\hline Sikh & 82.4 & 17 & 100 & 8 \\
\hline Muslim & 77.1 & 83 & 87.5 & 16 \\
\hline Christian & 57.9 & 235 & 68.5 & 124 \\
\hline Jewish & 35.7 & 28 & 33.3 & 20 \\
\hline Hindu & 20.8 & 24 & 80.0 & 9 \\
\hline Mixed-faith & 60.0 & 15 & 77.8 & \\
\hline
\end{tabular}

Table 2: $\quad$ Participants Who 'Strongly Agreed' or 'Agreed' that 'My Religious Tradition Prioritizes the Interest of Men'

\begin{tabular}{|c|c|c|c|c|}
\hline $\begin{array}{c}\text { Religious } \\
\text { identification }\end{array}$ & $\begin{array}{c}\text { Percentage of } \\
\text { women }\end{array}$ & $N$ & $\begin{array}{c}\text { Percentage of } \\
\text { men }\end{array}$ & $N$ \\
\hline Buddhist & 0.0 & 14 & 0.0 & 12 \\
\hline Sikh & 12.5 & 16 & 0.0 & 8 \\
\hline Muslim & 26.5 & 83 & 13.3 & 15 \\
\hline Christian & 26.6 & 233 & 27.4 & 124 \\
\hline Jewish & 53.6 & 28 & 50.0 & 20 \\
\hline Hindu & 37.5 & 24 & 35.0 & 10 \\
\hline Mixed-faith & 46.7 & 15 & 40.0 & \\
\hline
\end{tabular}


Table 3: $\quad$ Participants Who 'Strongly Agreed' or 'Agreed' that 'Religious Authority Figures (e.g. Clergy) Should be Male'

\begin{tabular}{|c|c|c|c|c|}
\hline $\begin{array}{c}\text { Religious } \\
\text { identification }\end{array}$ & $\begin{array}{c}\text { Percentage of } \\
\text { women }\end{array}$ & $N$ & $\begin{array}{c}\text { Percentage of } \\
\text { men }\end{array}$ & N \\
\hline Buddhist & 0.0 & 16 & 0.0 & 11 \\
\hline Sikh & 0.0 & 16 & 0.0 & 8 \\
\hline Muslim & 29.8 & 84 & 46.7 & 126 \\
\hline Christian & 15.7 & 236 & 26.2 & 18 \\
\hline Jewish & 17.9 & 28 & 11.1 & 20 \\
\hline Hindu & 8.3 & 24 & 10.0 & 9 \\
\hline Mixed-faith & 6.7 & 15 & 11.1 & \\
\hline
\end{tabular}

Table 4: $\quad$ Participants Who 'Strongly Agreed' or 'Agreed' that 'Men Should Provide Financially for the Family'

\begin{tabular}{|c|c|c|c|c|}
\hline $\begin{array}{c}\text { Religious } \\
\text { identification }\end{array}$ & $\begin{array}{c}\text { Percentage of } \\
\text { women }\end{array}$ & $n$ & $\begin{array}{c}\text { Percentage of } \\
\text { men }\end{array}$ & N \\
\hline Buddhist & 18.8 & 16 & 16.7 & 12 \\
\hline Sikh & 29.4 & 17 & 37.5 & 8 \\
\hline Muslim & 67.5 & 83 & 81.3 & 124 \\
\hline Christian & 30.0 & 237 & 44.4 & 17 \\
\hline Jewish & 32.1 & 28 & 11.8 & 19 \\
\hline Hindu & 29.2 & 24 & 47.4 & 8 \\
\hline Mixed-faith & 26.7 & 15 & 25.0 & \\
\hline
\end{tabular}


Table 5: $\quad$ Participants Who 'Strongly Agreed' or 'Agreed' that 'Women Should Have Primary Responsibility for Bringing up Children'

\begin{tabular}{|c|c|c|c|c|}
\hline $\begin{array}{c}\text { Religious } \\
\text { identification }\end{array}$ & $\begin{array}{c}\text { Percentage of } \\
\text { women }\end{array}$ & $n$ & $\begin{array}{c}\text { Percentage of } \\
\text { men }\end{array}$ & $n$ \\
\hline Buddhist & 0 & 15 & 0 & 12 \\
\hline Sikh & 5.9 & 17 & 12.0 & 25 \\
\hline Muslim & 43.4 & 83 & 40.0 & 15 \\
\hline Christian & 17.6 & 238 & 22.4 & 18 \\
\hline Jewish & 14.8 & 27 & 16.7 & 20 \\
\hline Hindu & 25.0 & 24 & 15.0 & 9 \\
\hline Mixed-faith & 13.3 & 15 & 11.1 & \\
\hline
\end{tabular}

